abcam

购买精品RabMAb重组兔单抗

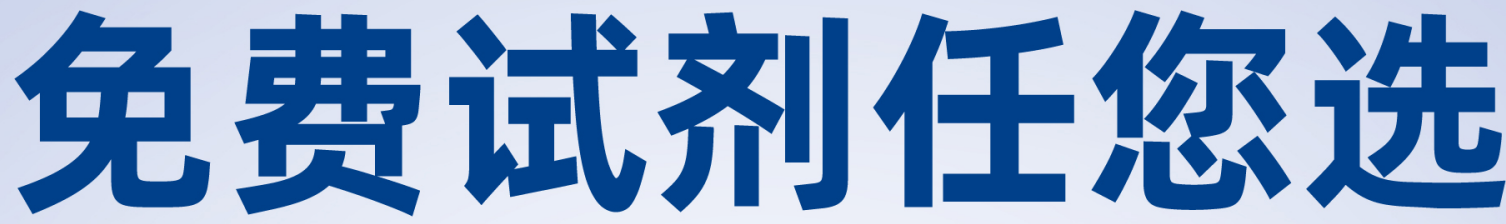

买一送一/买二送一

大才嫄里三

活动日期: 3.16-4.30 $\square^{2}+\mathrm{x}^{2} \mathrm{~g}$

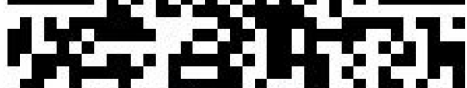

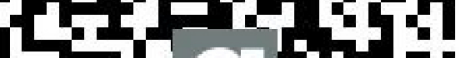

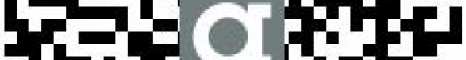
LE:-

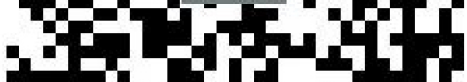

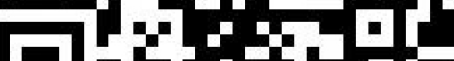

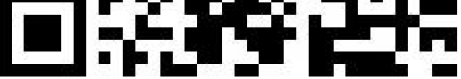

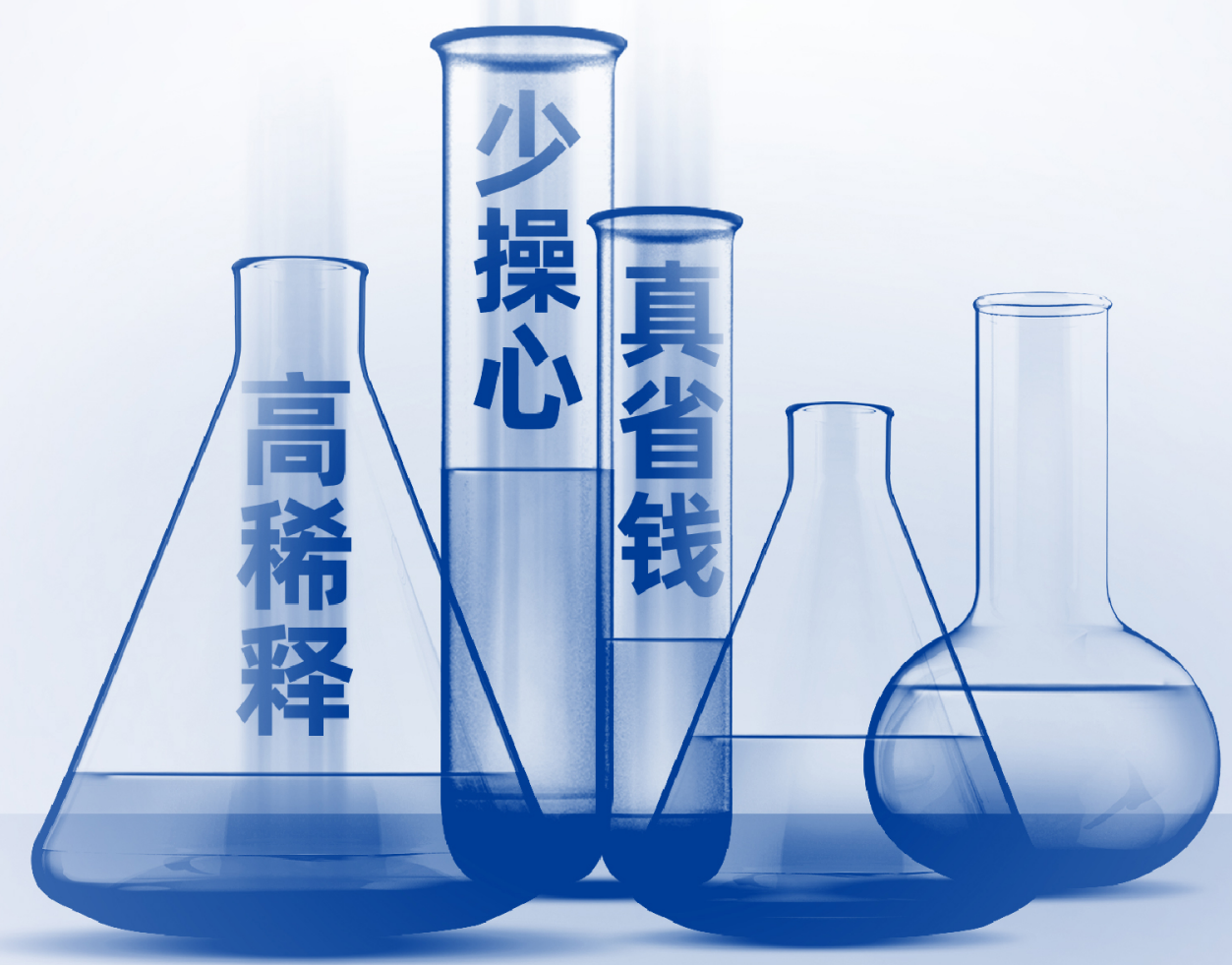




\section{Phospho-protein Analysis in Adherent Cells Using Flow Cytometry}

Renu Sharma, Amit Sharma, Atul Kumar* and Bithiah Grace Jaganathan*

Stem Cells and Cancer Biology Group, Department of Biosciences and Bioengineering, Guwahati, India *For correspondence: atul.bjg@gmail.com; bithiahgi@iitg.ac.in

[Abstract] Protein phosphorylation is one of the most important post-translational modifications, which acts as a reversible on or off switch for the activity of a large number of proteins. Analyzing the phosphorylation status of different proteins can reveal the alterations in the state of the cells in response to cellular damage, cancer and pharmaceutical drugs. Techniques such as mass spectrometry, radiolabeling, 2D-gel electrophoresis and western blotting are used to quantify protein phosphorylation. These assays can quantify phosphorylation in the bulk population of cells, however, flow cytometry can couple cell surface marker expression data with phosphorylation data to understand differential signaling in a sub-population within a heterogeneous population of cells. Our protocol describes the use of flowcytometry for rapid and single cell-based quantification of intracellular phospho-protein with the help of anti-phospho protein specific antibody.

Keywords: Phospho-protein, Protein phosphorylation, Signaling pathways, Intracellular staining, Single cell analysis

[Background] Protein phosphorylation is one of the most intensively studied post translation modifications. Protein phosphorylation acts as an "on" or "off" switch for the target protein activity and thereby modulates a large number of pathways and biological processes (Hunter, 1995). Phosphorylation of proteins is reversibly mediated by the action of two classes of enzymes namely; protein kinases and protein phosphatases, which together constitute the largest enzyme family, spanning $2 \%$ of the human genome (Venter, 2001; Manning et al., 2002; Alonso et al., 2004). It is estimated that one in three proteins undergoes phosphorylation during its lifetime. Given the scale of impact and importance of protein phosphorylation in dictating protein function, tight regulation of phosphorylation by protein kinases and phosphatases play vital role in signal transduction, cell differentiation, development, cell cycle control and metabolism (Delom and Chevet, 2006; Ardito et al., 2017). Protein kinases can be divided into two major groups based on the site of phosphorylation; serine/threonine kinases and tyrosine kinases (Roskoski, 2015). Whereas up to $86.4 \%$ of all phosphorylation modifications occur at serine residues, followed by $11.8 \%$ at threonine residues, less than $2 \%$ occur at tyrosine residues (Ardito et al., 2017).

The analysis of phospho-proteins is coupled with a myriad number of complications. Majority of proteins exist as a heterogeneous population, wherein the phosphorylated fraction is generally low in abundance and it exists in several different phosphorylated forms. The reversible nature of phosphorylation due to activity of phosphatases further necessitates crucial precautions during the processing of samples (Delom and Chevet, 2006). Mass spectroscopy analysis enables identification 
and quantification of post-translation modifications of proteins at a large scale (Steen et al., 2006; Junger and Aebersold, 2014; Pan et al., 2015). Two-dimensional gel electrophoresis can exploit the difference in isoelectric point of phosphorylated variant of a protein to quantify phosphorylated fraction (Guy et al., 1994). Use of phospho-protein specific antibodies conjugated with fluorophores allows single cell based rapid quantification with the help of flow cytometry (Krutzik and Nolan, 2003). Flow cytometry offers reduction in the number of processing steps as compared to western blotting and enables multiplex analysis of different types of cells and phospho-proteins (Krutzik et al., 2004; Davies et al., 2016). Whereas traditional biochemical assays can only quantify phosphorylation in the bulk population of cells but cannot determine the signaling differences in a sub-population within a heterogeneous population of cells, flow cytometry can couple cell surface marker expression data with phosphorylation data to understand differential response of different cell types to a ligand or inhibitor (Krutzik et al., 2004). Phospho-protein flow cytometry can be used to study signaling pathways in stem cells (Sonowal et al., 2013), cancer cells (Kumar et al., 2017) and understand cell-cell interaction (Kumar et al., 2018). We developed a reliable method to analyze phospho-proteins in adherent cells. Adherent cells require an additional step, where the cells have to be enzymatically detached from the cell growth surface and can lead to inactivation of phospho-proteins. This protocol described here can be used to successfully quantify the intracellular phospho-proteins in adherent cell types.

\section{Materials and Reagents}

1. Bio-hazard waste container (Tarsons, catalog number: 583254)

2. Cell culture dish, $100 \times 20 \mathrm{~mm}$ (Eppendorf, catalog number: 0030702115)

3. T25 flasks (Eppendorf, catalog number: 0030710118)

4. FACS tubes (Corning, catalog number: 352063)

5. Graduated centrifuge tubes, $15 \mathrm{ml}$ (Tarsons, catalog number: 546021)

6. Graduated centrifuge tubes, $50 \mathrm{ml}$ (Tarsons, catalog number: 546041)

7. Graduated $0.2-10 \mu \mathrm{l}$ micro-tips (Tarsons, catalog number: 521000 )

8. Graduated 2-200 $\mu \mathrm{l}$ micro-tips (Tarsons, catalog number: 521010 )

9. Graduated $200-1000 \mu \mathrm{l}$ micro-tips (Tarsons, catalog number: 521020 )

10. Serological glass pipettes, $10 \mathrm{ml}$ (Himedia, catalog number: CG316-1x10NO)

11. Sterile filtration unit $(0.22 \mu \mathrm{m})$ (Thermo Fisher Scientific, catalog number: 450-0020)

12. Storage vial, $5 \mathrm{ml}$ (Tarsons, catalog number: 523070 )

13. MDA-MB-231 breast cancer cell line (NCCS, Pune)

14. 10x Trypsin (2.5\%) (Thermo Fisher Scientific, catalog number: 15090-046)

15. Anti-Smad1 (pS463/pS465)/Smad8 (pS465/pS467) PE conjugated antibody (BD Biosciences, catalog number: 562509)

16. Bovine serum albumin (BSA) (Himedia, catalog number: MB083-5G)

17. De-ionized water $\left(\mathrm{dH}_{2} \mathrm{O}\right)$ (Merck, Elix Type 2 pure water)

18. Di-sodium hydrogen phosphate $\left(\mathrm{Na}_{2} \mathrm{HPO}_{4}\right)$ (Merck, catalog number: 61755005001046) 
19. DMEM-high glucose with L-Glutamine medium (DMEM-HG) (Sigma-Aldrich, catalog number: D5648-1L)

20. Fetal Bovine Serum (FBS) (Thermo Fisher Scientific, catalog number: 10270)

21. Formaldehyde solution $37-41 \%$ (w/v) (Merck, catalog number: 61780805001730 )

22. Hydrochloric acid $35 \%(\mathrm{HCl})$ (Merck, catalog number: 61762505001730)

23. Dimethyl sulfoxide (DMSO) (Sigma-Aldrich, catalog number: D8418-250ML)

24. LDN193189 hydrochloride (Sigma-Aldrich, catalog number: SML0559-5MG)

25. Methanol (Merck, catalog number: 82228305031730)

26. Potassium chloride (KCl) (Merck, catalog number: 61779205001730)

27. Potassium dihydrogen phosphate $\left(\mathrm{KH}_{2} \mathrm{PO}_{4}\right)$ (Merck, catalog number: 60487305001730)

28. Sodium bicarbonate $\left(\mathrm{NaHCO}_{3}\right)$ (Sigma-Aldrich, catalog number: S5761)

29. Sodium chloride ( $\mathrm{NaCl}$ ) (Merck, catalog number: 1.93206.0521)

30. Sodium hydroxide ( $\mathrm{NaOH}$ ) (Merck, catalog number: 61843805001730)

31. Trypan blue (Sigma-Aldrich, catalog number: T6146)

32. 100x Penicillin $(10,000$ Units/ml)-Streptomycin $(10,000$ Units/ml) antibiotic (Thermo Fisher Scientific, catalog number: 15140-122)

33. DMEM medium (see Recipes)

34. PBS (see Recipes)

35. $1 x$ Trypsin (see Recipes)

36. Heat inactivated FBS (see Recipes)

37. $0.4 \%$ trypan blue (see Recipes)

38. $4 \%$ formaldehyde solution (see Recipes)

39. Staining buffer (see Recipes)

40. LDN193189 Hydrochloride stock (see Recipes)

\section{Equipment}

1. Hemocytometer (Sigma-Aldrich, catalog number: Z359629-1EA)

2. Analytical balance (Sartorius, Quintix Analytical Balance $60,120 \mathrm{~g} \times 0.01,0.1 \mathrm{mg}$ )

3. Autoclave*

4. Biosafety cabinet class II (Thermo Fisher Scientific, model: 1300 series A2)

5. Centrifuge (Thermo Fisher Scientific, Sorvall Legend X1R centrifuge, catalog number: 75004260)

6. $\mathrm{CO}_{2}$ incubator (Thermo Fisher Scientific, Hera Cell 150i)

7. Flow cytometer (Becton Dickinson, FACS calibur and BD cell quest software)

8. Inverted microscope with camera (Zeiss, Axio Vert A1)

9. Vortex mixer (IKA, model: MS-3D)

10. Micropipettes (Thermo Fisher Scientific, Finnpipette F2-10 $\mu \mathrm{l}, 100 \mu \mathrm{l}$ and $1,000 \mu \mathrm{l}$ )

11. Pipette controller (Socorex, Profiller 446) 
12. Magnetic Stirrer (Tarsons, catalog number: 6090)

13. $4{ }^{\circ} \mathrm{C}$ refrigerator*

14. $-20^{\circ} \mathrm{C}$ refrigerator*

*Note: These items can be ordered from any qualified company.

15. $-80{ }^{\circ} \mathrm{C}$ refrigerator (Thermo Fisher Scientific, FORMA 88000 Series)

16. Water bath (Thermo Fisher Scientific, Labline water bath)

\section{Software}

1. FlowJo Software (FlowJo, LLC)

\section{Procedure}

For this study, MDA-MB-231 breast cancer cell line was purchased from National Centre for Cell Science (NCCS, Pune, India). The cells were cultured in cell growth medium (Recipe 1) in a $\mathrm{CO}_{2}$ incubator maintained at $5 \% \mathrm{CO}_{2}$ and $37^{\circ} \mathrm{C}$.

Note: Purchase cells from a recognized cell center and maintain them according to the instructions provided by the supplier.

A. Maintenance of cells

Note: The following steps are to be performed inside a biosafety cabinet class II following aseptic culture techniques.

Once the cells reach a confluency of $80 \%-90 \%$, subculture them as follows:

1. Aspirate the spent medium and collect it in a sterile $15 \mathrm{ml}$ centrifuge tube.

2. Wash twice with $1 \times$ PBS (Recipe 2).

3. Add $500 \mu \mathrm{l}$ of $1 \mathrm{x}$ Trypsin (Recipe 3 ) to the cells and incubate at $37^{\circ} \mathrm{C}$ for $2-3 \mathrm{~min}$. Notes:

a. Keep trypsin at room temperature for 5-10 min after retrieving from $4{ }^{\circ} \mathrm{C}$ before use.

b. The amount of trypsin recommended is for $60 \mathrm{~mm}$ dish or T25 flasks. For larger surface area, adjust the volume of trypsin used accordingly.

4. Gently tap along the side of dish to dislodge the cells. Do not leave cells in trypsin for more than $5 \mathrm{~min}$.

5. Add $1-2 \mathrm{ml}$ spent medium to neutralize the effect of trypsin and collect the cells in a labeled 15 $\mathrm{ml}$ centrifuge tube.

6. Centrifuge the cells at $300 \times g$ for $5 \mathrm{~min}$ at $4{ }^{\circ} \mathrm{C}$ to obtain the cell pellet. Discard the supernatant and re-suspend the pellet in $1 \mathrm{ml}$ of fresh growth medium.

7. Resuspend cells properly and take out small volume of cells $(50 \mu \mathrm{l})$ for counting.

8. Add an equal volume of $0.4 \%$ trypan blue (Recipe 5 ), mix and count viable cells using hemocytometer.

9. Seed cells in a $100 \mathrm{~mm}$ dish at a density of $5,000 \mathrm{cells} / \mathrm{cm}^{2}$ in $10 \mathrm{ml}$ of growth medium. Allow 
the cells to attach overnight.

Note: This seeding density is recommended for MDA-MB-231 cell line. Depending on the growth rate of cells used, seed cells at a density that will give at least $1 \times 10^{6}$ cells at the time of harvesting the cells for experiment.

10. After $24 \mathrm{~h}$, check the cells under the microscope for any contamination, add the stimulator/drugs/molecules for treatment at required concentration, and incubate the cells for the required amount of time in a $\mathrm{CO}_{2}$ incubator at $37^{\circ} \mathrm{C}$.

Note: For the current analysis, the cells were treated with $1 \mu M$ LDN193189 hypochloride (Recipe 8) for $24 \mathrm{~h}$.

B. Harvesting of cells

Notes:

a. Before starting the experiment go through the entire protocol and ensure the availability of all required materials and the temperature of water bath has reached $37^{\circ} \mathrm{C}$.

b. Pre-warm PBS at $37^{\circ} \mathrm{C}$ for $30 \mathrm{~min}$ and pre-warm trypsin at $37^{\circ} \mathrm{C}$ for no longer than $2-3 \mathrm{~min}$.

c. Temperature of the cells should be maintained at $37^{\circ} \mathrm{C}$ until the fixation step is completed, as fluctuation in temperature can lead to dephosphorylation of the phospho-proteins.

d. Perform the following steps in a $37^{\circ} \mathrm{C}$ water bath, but not in an incubator to ensure maintenance of uniform temperature during the procedure.

e. Handle the dish carefully, so that the dish is not contaminated with the water from the water bath.

1. Take the cells out from the $\mathrm{CO}_{2}$ incubator, discard the media immediately by pouring directly to bio-hazard waste container and place the dish in a $37^{\circ} \mathrm{C}$ water bath.

2. Add $10 \mathrm{ml}$ of pre-warmed $1 \times$ PBS along the wall of dish and swirl the dish gently to wash off the growth medium completely.

3. Discard the PBS and remove any remaining PBS by gently tapping the dish on tissue towel for 3-4 s.

4. Immediately place the dish in the water bath and add $900 \mu \mathrm{l}$ of pre-warmed 1x Trypsin (see Recipes). Gently swirl the dish to ensure uniform distribution of trypsin. Incubate for 1-3 min depending on the cells type.

Note: The amount of trypsin recommended in this step is for $100 \mathrm{~mm}$ dish. Adjust the volume according to the size of the dish used for experiment.

5. Gently tap the dish on the sides to ensure proper detachments of cells. A slight turbidity can be observed after trypsinization.

6. Add $100 \mu \mathrm{l}$ of pre-warmed FBS directly to the dish to neutralize the effect of trypsin and mix by pipetting.

Note: Steps B2-B6 should be performed in the water bath. 
C. Fixation of cells

Notes:

a. Perform Steps C2-C4 at room temperature.

b. Some phospho-proteins and/or antibodies might require a different fixation buffer, the user should check with the manufacturer before proceeding with the fixation of cells.

1. Add $1 \mathrm{ml} 4 \%$ formaldehyde (Recipe 6 ) directly to the cells, mix well by pipetting 3-4 times and transfer the cell suspension into a FACS tube.

Note: $4 \%$ paraformaldehyde can also be used instead of $4 \%$ formaldehyde for fixation following the same steps as mentioned above.

2. Vortex the cell suspension for about $10-15 \mathrm{~s}$ at $2500 \mathrm{rpm}$ and incubate for $10 \mathrm{~min}$ at room temperature.

3. Add $2 \mathrm{ml}$ of staining buffer (Recipe 7) to the cell suspension and centrifuge at $500 \times \mathrm{g}$ for $5 \mathrm{~min}$ at $4{ }^{\circ} \mathrm{C}$. Discard the supernatant without disturbing the pellet.

4. Wash the cells by resuspending the pellet in $2 \mathrm{ml}$ of ice-cold $1 \times$ PBS. Centrifuge at $500 \times g$ for 5 min at $4{ }^{\circ} \mathrm{C}$ and discard the supernatant.

D. Permeabilization of cells

1. While vortexing at a speed of $2500 \mathrm{rpm}$, add ice-cold $100 \%$ methanol ( $1 \mathrm{ml}$ for $1 \times 10^{6}$ cells) drop-wise to the cell pellet.

Note: Keep $100 \%$ methanol on ice for $2 \mathrm{~h}$ or alternatively at $-20^{\circ} \mathrm{C}$ overnight prior to starting the experiment

2. After addition of methanol, cover the tube with a cap to avoid methanol loss and incubate for at least $1 \mathrm{~h}$ at $4{ }^{\circ} \mathrm{C}$ (Figure 1 ).

Notes:

a. After methanol addition, cells can be stored for a week at $-20^{\circ} \mathrm{C}$.

b. Although most of the phospho-proteins and antibodies can work well with methanol mediated permeabilization, some phospho-proteins and/or antibodies might require a different permeabilization buffer, the user should check with the manufacturer before proceeding further. 


\section{biö-protocol

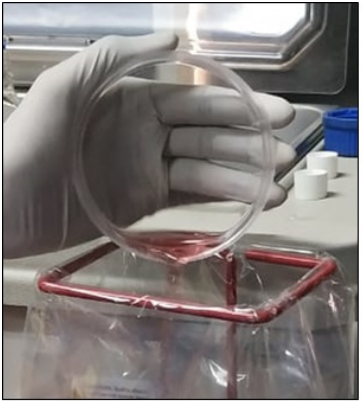

1. Discard growth media by pouring into a waste container

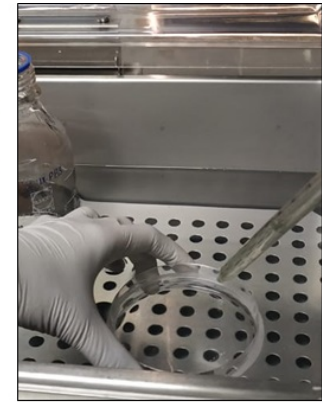

2. Wash with PBS while the dish is in the water bath

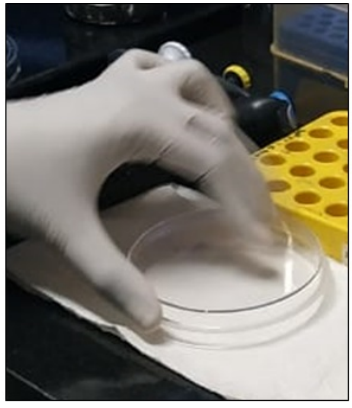

3. Remove excess PBS by taping on paper towel

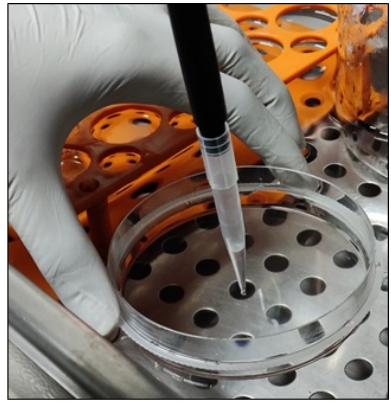

4. Add trypsin to the dish in the water bath

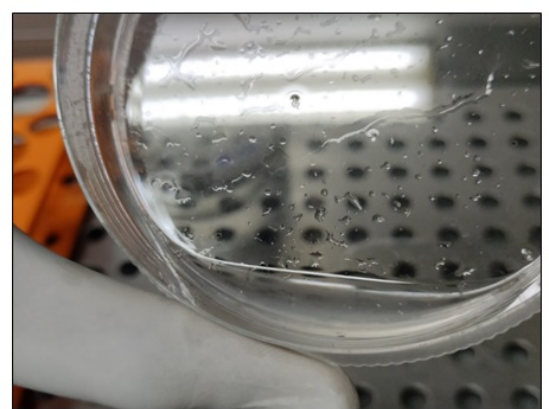

5. Cells in solution after trypsinization

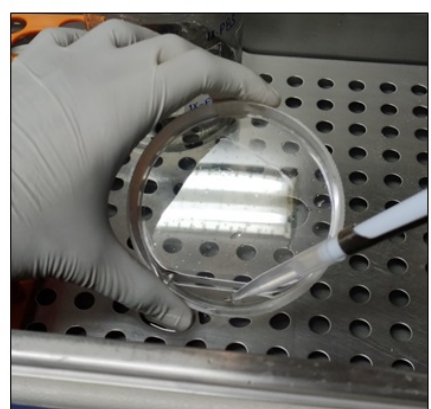

6. Add FBS/4\% formaldehyde directly to the cells in the dish

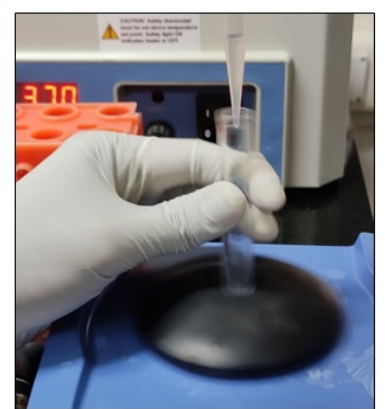

7. Add methanol dropwise while vortexing

Figure 1. Procedure describing sample processing for phospho protein staining

E. Phospho-protein staining and flow cytometry analysis

1. Add $4 \mathrm{ml}$ of staining buffer to the cells in methanol, centrifuge at $500 \mathrm{xg}$ for $5 \mathrm{~min}$ at $4{ }^{\circ} \mathrm{C}$ and discard the supernatant gently without disturbing the cell pellet.

2. Resuspend the cell pellet in $2 \mathrm{ml}$ of staining buffer. Centrifuge at $500 \times \mathrm{g}$ for $5 \mathrm{~min}$ at $4{ }^{\circ} \mathrm{C}$ and discard the supernatant.

3. Resuspend the pellet in $100 \mu \mathrm{l}$ of staining buffer and distribute $50 \mu \mathrm{l}$ of cell suspension per FACS tube for further staining.

Note: Make sure that at least $5 \times 10^{5}$ cells per tube are used for further staining for phosphoproteins.

4. Add phospho-specific primary unconjugated or fluorescent conjugated antibody to the cells according to the specifications of the manufacturer to one of the tubes and add isotype control to the other tube.

5. Gently vortex the suspension for $10 \mathrm{~s}$ and incubate at room temperature in the dark for $1 \mathrm{~h}$.

6. Add $2 \mathrm{ml}$ of staining buffer, centrifuge at $500 \times \mathrm{g}$ for $5 \mathrm{~min}$ at $4{ }^{\circ} \mathrm{C}$ and discard the supernatant carefully.

7. If a fluorescent conjugated antibody was used in Step E4, proceed directly to Step E9. If an unconjugated primary antibody was used, resuspend the cell pellet in $50 \mu \mathrm{l}$ of staining buffer. Add fluorescent dye conjugated secondary antibody and incubate at room temperature in the dark for $1 \mathrm{~h}$. 
8. Add $2 \mathrm{ml}$ of staining buffer, centrifuge at $500 \times \mathrm{g}$ for $5 \mathrm{~min}$ at $4{ }^{\circ} \mathrm{C}$ and discard the supernatant carefully.

9. Resuspend the pellet in $300 \mu \mathrm{l}$ of staining buffer and keep on ice.

10. Analyze the samples in a flow cytometer using proper settings for the fluorescence detection channels (Figure 2).

Note: Ensure that the excitation and emission wavelength of the fluorophore conjugatedantibody is compatible with the flow cytometer used.
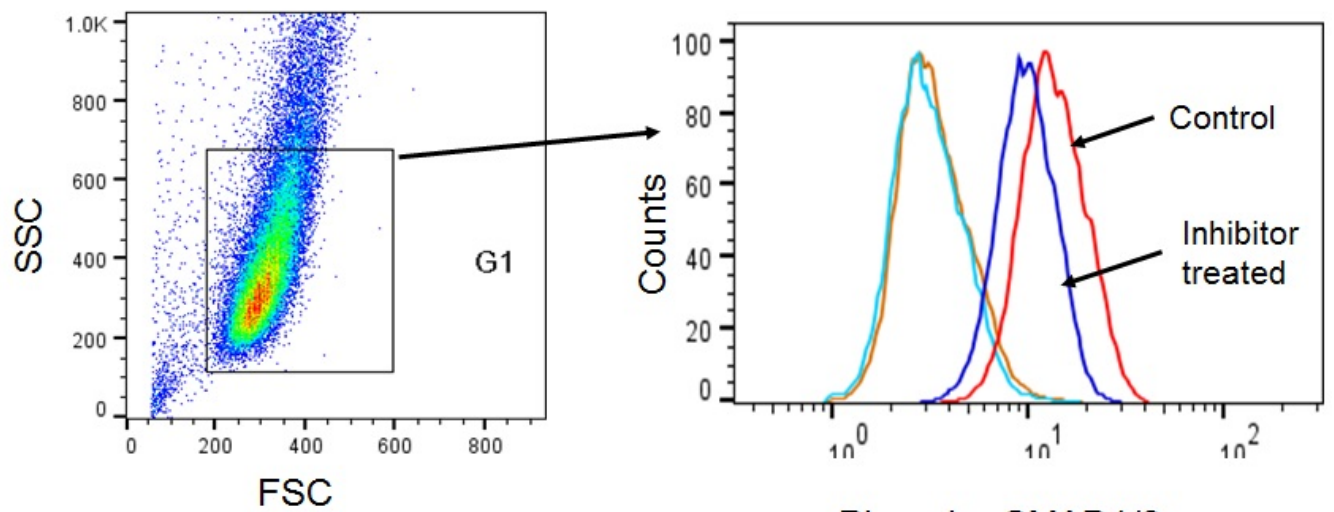

Phospho-SMAD1/8

Figure 2. Flow cytometric analysis of phospho-SMAD1/8. MDA-MB-231 cells were stained with PE conjugated anti-Smad1 (pS463/pS465)/Smad8 (pS465/pS467) antibody (PhosphoSMAD1/8). Cells were left untreated (Control) or treated with BMP inhibitor LDN193189 (Inhibitor treated). Orange line is the unstained control for control cells and light blue line is the unstained control for inhibitor treated cells.

\section{Data analysis}

The flow cytometry data of the phospho-protein staining was analyzed using FlowJo software. Cell population was selected by gating in FSC vs. SSC plot to remove the cell debris. Histograms were plotted to show the differences between isotype/unstained controls versus stained sample and treated versus untreated conditions. This protocol shows representative data for one phosphoprotein and does not include any statistical analysis.

\section{$\underline{\text { Notes }}$}

It is important to use antibodies that were tested for flow cytometry and detect only phospho form of the protein of interest. 


\section{Recipes}

1. DMEM medium

DMEM-HG (high glucose) basal medium:

$10 \mathrm{~g}$ DMEM-HG media powder

$3.7 \mathrm{~g}$ sodium bicarbonate

$10 \mathrm{ml}$ 100x Penicillin-Streptomycin antibiotic solution

Make up the volume to $1 \mathrm{~L}$ with autoclaved deionized $\mathrm{H}_{2} \mathrm{O}$

Adjust $\mathrm{pH}$ to $\sim 7.0$ with $5 \mathrm{M} \mathrm{HCl}$ as $\mathrm{pH}$ tends to increase after filtration

Sterilize by filtration using a sterile filtration unit $(0.22 \mu \mathrm{m})$

Can be stored at $4{ }^{\circ} \mathrm{C}$ for up to 2 months

\section{Cell growth medium:}

$10 \%$ FBS in DMEM-HG basal medium

Sterilize by filtration using a sterile filtration unit $(0.22 \mu \mathrm{m})$

Store at $4{ }^{\circ} \mathrm{C}$ and use within two weeks

2. Phosphate buffered saline (PBS)

\section{0x PBS:}

$80 \mathrm{~g} \mathrm{NaCl}$

$2 \mathrm{~g} \mathrm{KCl}$

$$
14.4 \mathrm{~g} \mathrm{Na}_{2} \mathrm{HPO}_{4}
$$

$2.4 \mathrm{~g} \mathrm{KH}_{2} \mathrm{PO}_{4}$

Add all salts in $800 \mathrm{ml}$ of autoclaved deionized $\mathrm{dH}_{2} \mathrm{O}$, and allow it to stir for $1 \mathrm{~h}$ at room temperature using a magnetic stirrer

Make up the volume to $1 \mathrm{~L}$ with deionized water

Sterilize by filtration using a sterile filtration unit $(0.22 \mu \mathrm{m})$

Store at room temperature

\section{1x PBS:}

Dilute 10x PBS ten times ( $1 \mathrm{ml}$ in $10 \mathrm{ml}$ ) in $\mathrm{H}_{2} \mathrm{O}$

Adjust $\mathrm{pH}$ to 7.4 with $5 \mathrm{M} \mathrm{NaOH}$ and autoclave at $121^{\circ} \mathrm{C}$ for $20 \mathrm{~min}$

3. $1 x \operatorname{Trypsin}(0.25 \%)$

$1 \mathrm{ml}$ of $10 \mathrm{x}$ trypsin

$9 \mathrm{ml}$ of sterile PBS

Prepare $5 \mathrm{ml}$ aliquots for use

Store aliquots at $-20^{\circ} \mathrm{C}$ for long term storage

Thaw at room temperature and store at $4{ }^{\circ} \mathrm{C}$ for short term use up to 1 weekl

4. Heat inactivated FBS

Heat inactivate FBS by incubating at $56{ }^{\circ} \mathrm{C}$ for $1 \mathrm{~h}$ in a water bath and store at $-20^{\circ} \mathrm{C}$ as $50 \mathrm{ml}$ aliquots

5. $0.4 \%$ trypan blue 
$0.04 \mathrm{~g}$ of Trypan blue (dye composition 40\%)

$10 \mathrm{ml}$ of $1 \times \mathrm{PBS}$

Filter using a sterile filtration unit $(0.22 \mu \mathrm{m})$

Store aliquots at $4{ }^{\circ} \mathrm{C}$ for long term storage

6. $4 \%$ formaldehyde solution

Dilute $37 \%-41 \%$ formaldehyde solution 10 times in $1 \times$ PBS

$1 \mathrm{ml}$ of $37 \%-41 \%$ formaldehyde solution

$9 \mathrm{ml}$ of $1 \mathrm{x}$ PBS

Mix it well by inverting 4-5 times

Prepare immediately before use

Keep at room temperature

7. Staining Buffer

$0.5 \mathrm{~g} \mathrm{BSA}$

$100 \mathrm{ml}$ of $1 \times$ PBS

Stir to dissolve

Store at $4^{\circ} \mathrm{C}$ up to 1 week

8. LDN193189 Hydrochloride stock

Dissolve $5 \mathrm{mg}$ in $1.23 \mathrm{ml}$ of DMSO to obtain $10 \mathrm{mM}$ stock

Store at $-20^{\circ} \mathrm{C}$ as aliquots of $20 \mu \mathrm{l}$ each

Thaw on ice before use

\section{Acknowledgments}

This work was supported by funds from Indian Council of Medical Research (ICMR), Govt. of India and Department of Science and Technology (DST), Govt. of India. RS and AS are supported by fellowship from Ministry of Human Resource and Development (MHRD), Govt. of India. This protocol was adapted from Kumar et al. (2017 and 2018).

\section{Competing interests}

The authors declare no competing interests.

\section{References}

1. Alonso, A., Sasin, J., Bottini, N., Friedberg, I., Friedberg, I., Osterman, A., Godzik, A., Hunter, T., Dixon, J. and Mustelin, T. (2004). Protein tyrosine phosphatases in the human genome. Cell 117(6): 699-711.

2. Ardito, F., Giuliani, M., Perrone, D., Troiano, G. and Muzio, L. L. (2017). The crucial role of protein phosphorylation in cell signaling and its use as targeted therapy. Int J Mol Med 40(2): 271-280. 
3. Davies, R., Vogelsang, P., Jonsson, R. and Appel, S. (2016). An optimized multiplex flow cytometry protocol for the analysis of intracellular signaling in peripheral blood mononuclear cells. $J$ Immunol Methods 436: 58-63.

4. Delom, F. and Chevet, E. (2006). Phosphoprotein analysis: from proteins to proteomes. Proteome Sci 4: 15.

5. Guy, G. R., Philip, R. and Tan, Y. H. (1994). Analysis of cellular phosphoproteins by two-dimensional gel electrophoresis: applications for cell signaling in normal and cancer cells. Electrophoresis 15(34): 417-440.

6. Hunter, T. (1995). Protein kinases and phosphatases: the yin and yang of protein phosphorylation and signaling. Cell 80(2): 225-236.

7. Junger, M. A. and Aebersold, R. (2014). Mass spectrometry-driven phosphoproteomics: patterning the systems biology mosaic. Wiley Interdiscip Rev Dev Biol 3(1): 83-112.

8. Krutzik, P. O., Irish, J. M., Nolan, G. P. and Perez, O. D. (2004). Analysis of protein phosphorylation and cellular signaling events by flow cytometry: techniques and clinical applications. Clin Immunol 110(3): 206-221.

9. Krutzik, P. O. and Nolan, G. P. (2003). Intracellular phospho-protein staining techniques for flow cytometry: monitoring single cell signaling events. Cytometry $A$ 55(2): 61-70.

10. Kumar, A., Anand, T., Bhattacharyya, J., Sharma, A. and Jaganathan, B. G. (2018). K562 chronic myeloid leukemia cells modify osteogenic differentiation and gene expression of bone marrow stromal cells. J Cell Commun Signal 12(2): 441-450.

11. Kumar, A., Bhattacharyya, J. and Jaganathan, B. G. (2017). Adhesion to stromal cells mediates imatinib resistance in chronic myeloid leukemia through ERK and BMP signaling pathways. Sci Rep. 7:9535.

12. Manning, G., Whyte, D. B., Martinez, R., Hunter, T. and Sudarsanam, S. (2002). The protein kinase complement of the human genome. Science 298(5600): 1912-1934.

13. Pan, L., Wang, L., Hsu, C. C., Zhang, J., lliuk, A. and Tao, W. A. (2015). Sensitive measurement of total protein phosphorylation level in complex protein samples. Analyst 140(10): 3390-3396.

14. Roskoski, R. (2015). A historical overview of protein kinases and their targeted small molecule inhibitors. Pharmacol Res 100: 1-23.

15. Sonowal, H., Kumar, A., Bhattacharyya, J., Gogoi, P. K. and Jaganathan, B. G. (2013). Inhibition of actin polymerization decreases osteogeneic differentiation of mesenchymal stem cells through p38 MAPK pathway. J Biomed Sci 20: 71.

16. Steen, H., Jebanathirajah, J. A., Rush, J., Morrice, N. and Kirschner, M. W. (2006). Phosphorylation analysis by mass spectrometry: myths, facts, and the consequences for qualitative and quantitative measurements. Mol Cell Proteomics 5(1): 172-181.

17. Venter, J. C. (2001). The sequence of the human genome (vol 292, pg 1304, 2001). Science 292(5523): 1838-1838. 